\title{
A APLICAÇÃO DA DECLARAÇÃO SOCIOLABORAL PELO TRIBUNAL ADMINISTRATIVO TRABALHISTA DO MERCOSUL
}

\section{THE APPLICATION OF THE SOCIOLABORAL DECLARATION BY THE MERCOSUR ADMINISTRATIVE-LABOUR COURT}

Recebimento: 20 dez. 2018

Aceitação: 31 ago. 2020

Larissa de Oliveira Elsner

Doutoranda em Direito

Afiliação institucional: Universidade do Vale do Rio dos Sinos - Unisinos - (São Leopoldo, RS, Brasil)

Lattes iD: http://lattes.cnpq.br/9215715351032855

Email: larissaelsner@hotmail.com

Luciane Klein Vieira

Doutora em Direito

Afiliação institucional: Universidade do Vale do Rio dos Sinos - Unisinos - (São Leopoldo, RS, Brasil)

Lattes iD: http://lattes.cnpq.br/6376329705906021

Email: lucianekleinvieira@yahoo.com.br

Como citar este artigo / How to cite this article (informe a data atual de acesso / inform the current date of access):

ELSNER, Larissa de Oliveira; VIEIRA, Luciane Klein. A aplicação da Declaração Sociolaboral pelo Tribunal Administrativo Trabalhista do Mercosul. Revista da Faculdade de Direito UFPR, Curitiba, v. 65, n. 3, p. 9-35, set./dez. 2020. ISSN 2236-7284. Disponível em: https://revistas.ufpr.br/direito/article/view/64037. Acesso em: 31 dez. 2020. DOI: http://dx.doi.org/10.5380/rfdufpr.v65i3.64037.

\section{RESUMO}

O presente artigo trata da origem e do conteúdo da Declaração Sociolaboral do Mercado Comum do Sul (Mercosul), tanto em sua versão de 1998 quanto em relação à reedição de 2015, buscando solucionar o seguinte problema de pesquisa: os princípios e direitos previstos em tal norma de soft law são efetivamente utilizados pelo Tribunal Administrativo Trabalhista do Mercosul (TAL), na fundamentação das sentenças destinadas à resolução de reclamações trabalhistas provenientes de funcionários do Mercosul? A metodologia escolhida para o tratamento da proposta é de natureza qualitativa, tanto bibliográfica como documental, e utiliza o método de caso para a análise de quatro sentenças proferidas e publicadas pelo TAL até 30 de agosto de 2020. Verificou-se que, ainda que o Tribunal reconheça a aplicação da Declaração Sociolaboral na solução das reclamatórias trabalhistas dos funcionários do Mercosul (o que já representa um avanço), não faz referência a ela como fundamento jurídico para as suas decisões. Conclui-se que a aplicação da Declaração Sociolaboral do Mercosul é de responsabilidade tanto dos trabalhadores quanto dos tribunais e dos Estados Partes do Mercosul.

\section{PALAVRAS-CHAVE}

Direito do Trabalho. Declaração Sociolaboral do Mercosul. Tribunal Administrativo Trabalhista do Mercosul. 


\begin{abstract}
This article deals with the origin and content of the Socialaboral Declaration of the Southern Common Market (Mercosur for its Spanish initials), both in its 1998 version and with respect to the 2015 reissue, in order to solve the following research problem: are the principles and rights foreseen in such a soft law rule effectively used by the Mercosur Administrative-Labour Court (TAL for its Spanish initials) in the preparation of sentences dealing with labor claims from Mercosur employees? The methodology chosen to approach the proposal is qualitative in nature, both bibliographical and documentary, and use the case method for the analysis of four judgments handed down by the TAL until August $30^{\text {th }}$, 2020. It was found that, although the Court recognizes the application of the Sociolaboral Declaration in the solution of the labor claims of Mercosur employees (which already represents an advance), it does not refer to it as a legal basis for its decisions. It is concluded that the application of the Mercosur Sociolaboral Declaration is the responsibility of both, workers and courts, as well as the States Parties to Mercosur.
\end{abstract}

\title{
KEYWORDS
}

Labor Law. Sociolaboral Declaration of Mercosur. Mercosur Administrative-Labour Court.

\section{INTRODUÇÃO}

A primeira versão da Declaração Sociolaboral foi apresentada pelos Estados Partes do Mercado Comum do Sul (Mercosul) ${ }^{1}$ em 1998, tendo sido resultado de reiteradas críticas lançadas ao bloco econômico pela ausência de normas específicas quanto às questões sociolaborais no espaço integrado. Em 2015, a Declaração foi revisada e reeditada pelos Estados Partes, tendo sido mantida a sua estrutura básica original, porém com a inclusão de alguns princípios e direitos. Em seu conteúdo, foram previstos direitos e princípios destinados aos trabalhadores e empregadores do Mercosul, bem como compromissos a serem cumpridos pelos Estados Partes.

Nessa linha, em que pese a norma de soft law referida não ter sido dotada de cogência ou poder de vinculação, na medida em que os Estados não optaram por convertê-la num tratado ou norma proveniente dos órgãos decisórios do Mercosul, tem-se como base os elementos previstos no Tratado de Assunção ${ }^{2}$ e em normas internacionais que garantem direitos aos trabalhadores, tais como as convenções da Organização Internacional do Trabalho (OIT) ${ }^{3}$ e os instrumentos do Direito Internacional dos Direitos Humanos. Ainda, salienta-se que a Declaração Sociolaboral prevê a aplicabilidade daqueles princípios e direitos às legislações nacionais dos Estados Partes, com o que

1 O Mercosul é um bloco de integração criado pelo Tratado de Assunção, em 1991, e conta com a Argentina, o Brasil, o Paraguai e o Uruguai como Estados Partes na condição de membros originários. No ano de 2012, foi aprovado o ingresso da Venezuela ao bloco, mas esse país se encontra atualmente suspenso, por ruptura do compromisso democrático.

2 O Tratado de Assunção foi celebrado em 26 de março de 1991, entre Argentina, Brasil, Paraguai e Uruguai, e entrou em vigor em 19 de novembro de 1991.

3 Sobre a forma de criação, aprovação e entrada em vigência das Convenções e Declarações da OIT, ver: VIEIRA, 2019, p. 11-41. 
se observa que o instrumento referido preza por uma sorte de poder moral ou valorativo, já que tem o intuito de influenciar a elaboração e aplicação da legislação interna dos Estados referidos.

Nesse cenário, o presente artigo indaga se a Declaração Sociolaboral tem sido aplicada na solução das reclamatórias trabalhistas dos funcionários do Mercosul, que são julgadas pelo Tribunal Administrativo Trabalhista do bloco (TAL). Ante esse problema de pesquisa, a hipótese de trabalho que se apresenta é a de que a Declaração Sociolaboral não é utilizada pelo TAL na solução dos conflitos trabalhistas emergentes das relações laborais de tais funcionários, o que se pretende demonstrar mediante o estudo das quatro sentenças proferidas por esse tribunal até 30 de agosto de 2020.

Assim, para resolver o problema de pesquisa apresentado, este artigo será estruturado em dois tópicos: no primeiro, será estudado o conteúdo da Declaração Sociolaboral, tanto na versão de 1998 quanto na de 2015, o histórico de sua origem e as críticas apresentadas acerca da sua aplicabilidade; no segundo, objetiva-se verificar a estrutura do TAL, sua competência, os regulamentos que o regem e o direito aplicado, para, logo após, analisar de forma individual quatro sentenças proferidas pelo TAL, com o objetivo de verificar se os trabalhadores requerem a postulação da Declaração Sociolaboral do Mercosul em suas ações e se o Tribunal aplica o conteúdo dessa norma de soft law em suas decisões.

Ainda, o presente estudo se vale de uma metodologia qualitativa, do tipo bibliográfica e documental, buscando reunir informações da doutrina e da jurisprudência do TAL, razão pela qual igualmente emprega o método do estudo de caso, a fim de explorar as decisões publicadas referentes às reclamatórias trabalhistas propostas pelos funcionários do Mercosul. Sendo assim, devido ao objetivo de análise das sentenças do TAL, tomou-se como fonte de pesquisa o site do Tribunal Permanente de Revisão do Mercosul (TPR), no espaço destinado exclusivamente ao TAL, no qual estão publicadas as quatro sentenças pronunciadas por esse tribunal até a data final de elaboração deste estudo, qual seja, 30 de agosto de 2020. Portanto, as conclusões apresentadas limitam-se às decisões analisadas, sendo possível e esperado que, em futuras demandas, possa existir um emprego efetivo da Declaração Sociolaboral do Mercosul nas sentenças emitidas pelo tribunal referido.

\section{A DECLARAÇÃO SOCIOLABORAL DO MERCOSUL}

Desde a sua formação enquanto bloco de integração, o Mercosul não evidenciou a preocupação acerca da questão sociolaboral nos Estados Partes, tal como refere Cordeiro (2000, p. 131): “A questão sócio-laboral efetivamente não ocupa um papel significante na agenda do Mercosul. 
Todavia não podemos deixar de mencionar a existência de algumas regulações e institutos relevantes sobre a matéria”. Entre as regulações existentes intenta-se, neste artigo, analisar a Declaração Sociolaboral do $\mathrm{Mercosul}^{4}$, tanto em seu formato original, de 1998, quanto na sua reedição de 2015, a fim de verificar o conteúdo de tal documento e sua importância na solução das controvérsias apresentadas ao TAL.

A origem da Declaração Sociolaboral do Mercosul, nas palavras de Peduzzi (2005, p. 1), corresponde a uma “[...] resposta dos Estados Partes às reiteradas reclamações quanto ao enfoque do bloco regional”, haja vista que se observava um “[...] excesso de influência dos aspectos comerciais, econômicos e tributários da integração, pelo que em muito se descuidava das demandas sociais daí advindas” (PEDUZZI, 2005, p. 1). Contudo, não apenas essa declaração se originou a partir das reiteradas críticas às dimensões não sociais do bloco, mas também a própria criação de um grupo de trabalho, responsável por harmonizar as questões sociolaborais do Mercosul, foi resultado das reclamações referidas. Entre as justificativas políticas, destaca-se a “[...] necessidade de que os aspectos laborais recebessem um adequado tratamento, de modo a assegurar que o processo de integração se visse acompanhado de uma efetiva melhora nas condições de trabalho” (GARCIA JÚNIOR, 1997, p. 15).

Ante esse cenário de negligência em relação aos setores sociais, “[...] somente após muita pressão, principalmente advinda de órgãos representativos de diversas categorias profissionais, em seus respectivos países, é que se criou o Subgrupo de Trabalho $\mathrm{n}^{\circ} 1^{5}$ ” (NORRIS, 1998, p. 31), responsável por avaliar as demandas em matéria trabalhista e previdenciária para, posteriormente, apresentar ao Grupo do Mercado Comum (GMC) as recomendações de possíveis ações que deveriam ser adotadas pelos Estados Partes. Porém, o Subgrupo de Trabalho não foi tão efetivo quanto previsto na proposta inicial, conforme se vê:

A proposta de atuação do Subgrupo $\mathrm{n}^{\circ} 11$ foi muito ambiciosa e sua estrutura restou bastante complexa e hierarquizada. Os objetivos não foram conquistados integralmente, e os assuntos das Comissões, em sua maior parte, não foram objeto de recomendações ao Grupo do Mercado Comum (CORDEIRO, 2000, p. 133).

4 É interessante referir que, na cidade do México, em 2009, foi aprovado, pela Associação Latino-Americana de Advogados Trabalhistas, um instrumento de soft law denominado Carta Sociolaboral Latino-Americana, que, tal qual a Declaração Sociolaboral do Mercosul, contempla uma série de recomendações dirigidas aos Estados, pautadas em direitos trabalhistas já consagrados pelas Convenções da OIT. Para mais detalhes sobre a carta referida, ver: RAMÍREZ, 2011, p. 7-14.

5 Em 1991, o GMC criou o Subgrupo de Trabalho $\mathrm{n}^{\circ}$ 11, com o objetivo de harmonizar o direito interno dos Estados Partes na temática do direito do trabalho, considerando a necessidade de que os aspectos vinculados a esta área fossem adequadamente tratados de modo a assegurar que o processo de integração fosse acompanhado de uma efetiva melhoria nas condições de trabalho nos países da sub-região (MERCOSUL, 1991). 
A estrutura do Subgrupo de Trabalho $\mathrm{n}^{\circ} 11$ foi composta inicialmente por oito comissões, sendo elas: a) relações individuais de trabalho; b) relações coletivas de trabalho; c) emprego; d) formação profissional; e) saúde e seguridade no trabalho; f) previdência social; g) legislações específicas de algumas de suas categorias; e h) princípios. Entre essas oito comissões, Peña (2014, p. 34-35) destaca que a Comissão dos Princípios foi a que ficou responsável pelas tarefas fundamentais, sendo elas a ratificação das Convenções da OIT e a elaboração de uma carta de direitos fundamentais ou carta social que contemplasse todos os direitos dos trabalhadores do Mercosul.

Ainda que não se tenha alcançado todos os objetivos propostos, cabe referir que foi o Subgrupo $n^{0} 11$ que iniciou os trabalhos para a posterior criação da Declaração Sociolaboral do Mercosul, assinada em 10 de dezembro de 1998, pelos chefes de Estado dos Estados Partes do Mercosul $^{6}$, com o objetivo de ser “[...] a proclamação solene dos direitos sociais fundamentais reconhecidos” (ERMIDA URIARTE, 2003, p. 247).

\subsection{A DECLARAÇÃO SOCIOLABORAL DO MERCOSUL DE 1998}

A Declaração Sociolaboral de 1998 foi estruturada com um preâmbulo ${ }^{7}$ e vinte e cinco artigos, subdivididos em quatro partes intituladas direitos individuais, direitos coletivos, outros direitos e aplicação e seguimento. Em seu preâmbulo, verificam-se os motivos pelos quais os Estados Partes consideraram relevante a existência da Declaração Sociolaboral, remetendo-se inicialmente ao conteúdo do Tratado de Assunção (1991), no que diz respeito ao compromisso de “[...] promover a modernização de suas economias para ampliar a oferta de bens e serviços disponíveis e, em consequência, melhorar as condições de vida de seus habitantes” (MERCOSUL, 1998).

Ademais, insurgem-se como razões de sua adoção o fato de que os Estados Partes - bem como membros da OIT - ratificaram as suas principais convenções que garantem os direitos

6 Os chefes de Estado, na ocasião, eram: Carlos Saúl Menem (presidente da Argentina), Fernando Henrique Cardoso (presidente do Brasil), Raúl Alberto Cubas Grau (presidente do Paraguai) e Julio María Sanguinetti (presidente do Uruguai).

7 Cumpre esclarecer que a doutrina brasileira, tal como cita Tavares (2018, p. 173), considera que "os preâmbulos, rigorosamente, não integram o corpo da norma constitucional, mas lhe são sempre contemporâneos e agregados. Nos preâmbulos é comum encontrar-se a evocação de Deus, bem como dos princípios mais sublimes para o povo, como a Justiça, a liberdade e outros. No preâmbulo o legislador constituinte aponta, pois, os ideais que o inspiraram e que se impregnam no texto que se apresenta à nação”. Tal entendimento também é reproduzido pela jurisprudência do Supremo Tribunal Federal, como se pode verificar na decisão da Adin nº 2.076/AC, de 15/08/2002, cuja ementa refere: "CONSTITUCIONAL. CONSTITUIÇÃO: PREÂMBULO. NORMAS CENTRAIS. Constituição do Acre. I. Normas centrais da Constituição Federal: essas normas são de reprodução obrigatória na Constituição do Estadomembro, mesmo porque, reproduzidas, ou não, incidirão sobre a ordem local. Reclamações 370-MT e 383-SP (RTJ 147/404). II. - Preâmbulo da Constituição: não constitui norma central. Invocação da proteção de Deus: não se trata de norma de reprodução obrigatória na Constituição estadual, não tendo força normativa. III. - Ação direta de inconstitucionalidade julgada improcedente” (grifo nosso). 
essenciais dos trabalhadores, bem como se comprometeram com diversas normas do sistema de proteção dos direitos humanos ${ }^{8}$. Em síntese, os parágrafos finais do preâmbulo da Declaração Sociolaboral confirmam que os princípios e direitos consagrados neste documento abrangem todos os trabalhadores domiciliados nos Estados Partes, sem prejuízo dos dispositivos previstos nos ordenamentos jurídicos nacionais.

No tocante a esses direitos e princípios previstos, a Declaração foi estruturada em quatro segmentos, iniciando-se pelos direitos individuais. Nesta primeira parte, constam sete artigos, que são agrupados por Borrego (2010) em quatro modalidades distintas de direitos, a saber: o direito de não discriminação, presente nos três primeiros artigos da Declaração, em que se “[...] enfatiza sobre as oportunidades de emprego e ocupação, sem distinção ou exclusão baseada em raça, cor, ideologia, condição social” (BORREGO, 2010, p. 413); o direito dos trabalhadores migrantes e fronteiriços, que, “[...] independente de sua nacionalidade, têm direito a ajuda, informação, proteção e igualdade de direitos e condições de trabalho reconhecidas aos nacionais do país em que estiverem exercendo suas atividades” (BORREGO, 2010, p. 413), previsto no artigo 4º o direito à eliminação do trabalho forçado e abolição efetiva do trabalho infantil, indicado nos artigos $5^{\circ}$ e $6^{\circ}$; e, por fim, o direito dos empregadores, indicado no artigo $7^{\circ}$, em que “[...] se reconhece o direito do empregador a organizar e dirigir econômica e tecnicamente a empresa, em conformidade com as legislações e práticas nacionais” (BORREGO, 2010, p. 413).

Da subdivisão proposta por Borrego é possível visualizar a relevância da proteção ao indivíduo imposta pela Declaração, a exemplo de outros diplomas internacionais da OIT, como, por exemplo, a Convenção $n^{0}$ 111, ratificada pelo Brasil em 1965, que proíbe qualquer forma de discriminação em matéria de emprego e ocupação (BRASIL, 2019). Isto se explica pelo fato de que todo o texto da Declaração foi elaborado com base nas convenções da OIT, ratificadas pelos Estados Partes, como indicado no preâmbulo desse texto. Logo, o que se verifica na Declaração é uma referência expressa aos direitos individuais protegidos por esses instrumentos internacionais.

Por sua vez, os direitos coletivos são apresentados nos artigos $8^{\circ}$ a $13^{\circ}$, que garantem a proteção da liberdade de associação para empregadores e trabalhadores, da liberdade sindical e de filiação, do direito à negociação coletiva e do direito à greve, este último garantido a todos os trabalhadores e às organizações sindicais, em conformidade com as disposições nacionais vigentes. Acerca de tais direitos, salienta-se que:

8 No tocante à pauta de direitos humanos, Feferbaum (2017, p. 157) esclarece que o Mercosul é um exemplo de bloco econômico que insere em suas normas o compromisso dos Estados Partes com esses instrumentos normativos. 
No campo dos direitos coletivos, também não apresentou a Declaração qualquer vanguardismo. Da mesma forma que na regulação dos direitos individuais, os temas abordados são questões já consolidadas e integrantes de outras normas internacionais de caráter principiológico. Foi assegurado o direito à liberdade de associação dos trabalhadores a entidades sindicais, na forma da legislação vigente nos Estados Partes (art. 8º), bem como se consagrou o princípio da liberdade sindical através da garantia da filiação sindical, a proteção à dispensa imotivada dos participantes dos movimentos sindicais e a garantia do direito de representação nos processos de negociação coletiva (art. $9^{\circ}$ ). No que concerne ao direito à greve, a postura da Declaração foi apenas no sentido de referendá-lo na forma das legislações dos países do Mercosul [...]. (CORDEIRO, 2000, p. 139).

Inserido ainda neste rol de direitos coletivos, o artigo $13^{\circ}$ tenta reconhecer o diálogo social promovido pelos Estados Partes como um meio para a garantia do crescimento econômico sustentável, com justiça social, para os povos pertencentes ao Mercosul. Como destaca Borrego (2010, p. 415), “[...] uma das maiores realizações dos atores signatários da Declaração Sociolaboral é a concretização dos mecanismos de participação, como o diálogo social e o acordo sobre temas de interesse regional”.

Nos artigos que compõem os intitulados outros direitos, verifica-se uma “[...] nítida preocupação, pelo menos de caráter retórico, com a questão do desemprego” (CORDEIRO, 2000, p. 139). Isso se explica pelo fato de que dos seis artigos que compõem a seção, os três primeiros preveem expressamente o compromisso dos Estados Partes em fomentar o emprego, bem como em criar mecanismos de proteção contra o desemprego, sendo indicado, nessa linha, o desenvolvimento dos recursos humanos e a formação profissional. Os outros artigos destinam-se à proteção da saúde e segurança do trabalho, comprometendo-se os Estados Partes a organizar inspeções para averiguar as condições de exercício do trabalho. Por fim, o artigo $19^{\circ}$ encerra a seção com a previsão do direito à seguridade social ${ }^{9}$ aos trabalhadores do Mercosul, em conformidade com as respectivas legislações nacionais.

Os últimos cinco artigos da Declaração compõem a denominada seção de aplicação e seguimentos, em que algumas das possíveis ações práticas a serem realizadas pelos Estados Partes são indicadas com o intuito de proteger os direitos fundamentais previstos neste documento. A primeira delas consiste na recomendação da instituição de uma comissão sociolaboral regional, que será responsável por atribuições como a de examinar dúvidas sobre a aplicação dos termos da Declaração. Essa comissão “[...] é de composição paritária e tem caráter promocional e não

9 Referente à seguridade social, cabe informar que este tema está regulado no Acordo Multilateral de Seguridade Social do Mercosul, de 1997, que foi promulgado pelo Brasil mediante o Decreto $\mathrm{n}^{0} 5.722 / 2006$. Esse acordo reconhece o direito de todos os trabalhadores e seus familiares que exercerem atividades laborais em um dos Estados Partes do Mercosul, ainda que sejam estrangeiros, ao gozo da prestação contributiva pecuniária e de saúde referentes ao sistema de seguridade social. É importante salientar que cada Estado definirá sua legislação própria para a concessão dos benefícios, sendo que o Acordo somente estabelece o compromisso desses Estados em promover e regularizar o sistema de seguridade social (BRASIL, 2006). 
sancionador, ou seja, suas deliberações apenas se consubstanciam em meras recomendações sem qualquer coercibilidade (art.20)” (CORDEIRO, 2000, p. 139-140), o que igualmente corrobora o caráter de soft law da norma em comento. Por sua vez, a Resolução n ${ }^{0} 15 / 99$, que criou o órgão referido, determina que:

A Comissão pode formular planos, programas de ação e recomendações tendentes a fomentar
a palicação e o cumprimento da Declaração. Pode, também, examinar consultas, observações
e dúvidas a respeito da interpretação do documento, instrumento que poderia ser mais
utilizado por segmentos sociais, judiciais e governamentais, inclusive pelo Parlamento do
Mercosul. Ademais, pode elaborar análises e informes sobre o cumprimento da Declaração
Sociolaboral. A Comissão reúne-se ordinariamente duas vezes ao ano, com encontros
restritos aos membros e dois assessores por comissão, o que limita a participação de setores
interessados, como academia e sociedade civil e o conhecimento social acerca de seu
trabalho. As decisões são tomadas por consenso entre todos os membros (DRI, 2010, p. 204).

De qualquer sorte, cabe ainda referir a previsão constante do artigo $24^{\circ}$ da Declaração Sociolaboral, mediante o qual os Estados Partes concordaram com a necessidade de se revisar o texto da Declaração, no período de dois anos após sua adoção, com base nas propostas e subsídios formulados pela Comissão Sociolaboral ou por outros agentes. Como resultado dessa previsão, ainda que um pouco tarde, em julho de 2015, os chefes de Estado dos cinco Estados Partes do Mercosul ${ }^{10}$ firmaram finalmente o novo texto da Declaração Sociolaboral.

\subsection{A DECLARAÇÃO SOCIOLABORAL DO MERCOSUL DE 2015}

A estrutura desta declaração revisada manteve a organização apresentada pela versão original, contudo acrescentou dois novos capítulos ao texto: o Capítulo I, de título Princípios Gerais, composto por três artigos; e o Capítulo VI, acerca das Disposições Transitórias, composto, por sua vez, por dois artigos. Os capítulos originários da Declaração de 1998 foram mantidos em sua mesma definição, sendo eles o Capítulo II, dos Direitos Individuais; o Capítulo III, dos Direitos Coletivos; o Capítulo IV, Outros Direitos; e o Capítulo V, Aplicação e Seguimentos, totalizando 34 artigos (MERCOSUL, 2015).

Analisando-se o conteúdo do preâmbulo, pode-se observar que as razões existentes na Declaração de 1998 foram mantidas, quase que de forma idêntica, permanecendo o compromisso dos Estados Partes com as normas internacionais que integram o patrimônio jurídico da humanidade. Enquanto inovação, destaca-se o penúltimo parágrafo do preâmbulo, que em seu texto já indica

10 Os chefes de Estado que participaram da revisão da Declaração Sociolaboral de 1998 foram: Carlos Saúl Menem (Argentina); Fernando Henrique Cardoso (Brasil); Raúl Alberto Cubas Grau (Paraguai) e Julio María Sanguinetti (Uruguai). 
aqueles que seriam os princípios gerais dessa nova redação da Declaração Sociolaboral, como se observa à continuação:

Considerando que a Resolução sobre a promoção de empresas sustentáveis (OIT, 2007) reconhece que as empresas sustentáveis são fonte principal de crescimento, criação de riqueza e de emprego e que a promoção dessas empresas é ferramenta importante para se alcançar o trabalho decente, o desenvolvimento sustentável e a inovação que melhoram os níveis de vida e as condições sociais; [...]. (MERCOSUL, 2015, p. 2).

No tocante à sustentabilidade, cabe destacar que, também em 2015, a Organização das Nações Unidas (ONU) lançou a Agenda 2030 para o Desenvolvimento Sustentável, contendo um plano de ação destinado tanto aos Estados como às pessoas físicas e jurídicas, impulsando a realização de medidas durante o período de 15 anos, com o intuito de transformar o mundo num planeta mais sustentável e viável a longo prazo (ONU BRASIL, 2015). Tais ações foram organizadas em 17 objetivos (ODS) e 169 metas. A ONU definiu essa agenda como universal, pois engloba necessidades que são identificadas em todas as partes do mundo (como, por exemplo, a erradicação da pobreza e da fome), ainda que em proporções diferentes. Sobre o tema que se diz respeito, destacam-se os objetivos oito e 12, que tratam de questões relacionadas à Declaração Sociolaboral do Mercosul, sendo eles, respectivamente, a promoção do crescimento econômico, inclusivo e sustentável, do pleno emprego, e do trabalho decente; e a garantia de padrões de produção e de consumo sustentáveis (ONU BRASIL, 2015).

Retornando, pontualmente, ao conteúdo da Declaração de 2015, verifica-se que no primeiro capítulo do documento estão indicados os princípios gerais, iniciando pelo artigo $1^{\circ}$, que, com o título “definições”, busca esclarecer que, ainda que os termos utilizados sejam indicados no masculino (por exemplo, “trabalhadores” e “empregadores”), essas palavras compreendem os dois gêneros, abarcando igualmente as "trabalhadoras” e “empregadoras”. Na sequência, os artigos $2^{\circ}$ e $3^{\circ}$ apresentam os princípios referidos no preâmbulo, remetendo ao trabalho decente e às empresas sustentáveis.

Antes de se ater ao artigo transcrito, são importantes algumas informações acerca do conceito de trabalho decente, uma vez que este não é uma criação da Declaração Sociolaboral do Mercosul de 2015. Esse conceito foi empregado pela OIT, no preâmbulo de sua Constituição de 199911, em que se vislumbra, nas palavras de Silva e Mandalozzo (2013, p. 123), “[...] a preocupação

11 “O Trabalho Decente é o ponto de convergência dos quatro objetivos estratégicos da OIT: o respeito aos direitos no trabalho (em especial aqueles definidos como fundamentais pela Declaração Relativa aos Direitos e Princípios Fundamentais no Trabalho e seu seguimento, adotada em 1998: (i) liberdade sindical e reconhecimento efetivo do direito de negociação coletiva; (ii) eliminação de todas as formas de trabalho forçado; (iii) abolição efetiva do trabalho 
com o mundo do trabalho, a pessoa trabalhadora é possuidora de direitos básicos para sobrevivência não só em época produtiva, mas também para época posterior”. Logo, o conceito de trabalho decente é um objetivo a ser alcançado para a melhoria das condições de trabalho, sendo que tais fundamentos são essenciais a todos os trabalhadores, incluindo aqueles pertencentes ao Mercosul, que também estão vinculados ao ODS no 8 da Agenda 2030 (ONU BRASIL, 2015).

Portanto, ainda que não esteja de forma explícita, o princípio do trabalho decente indicado na Declaração Sociolaboral de 2015 compreende os objetivos almejados pela OIT, sendo que os Estados Partes são igualmente responsáveis pela realização de medidas práticas para que se concretizem tais aspirações. Já o artigo $2^{\circ}$ da Declaração limita-se a indicar o comprometimento dos Estados na realização de “[...] políticas ativas de trabalho decente” (MERCOSUL, 2015), considerando alguns dos objetivos que merecem estar presentes no momento da criação dessas políticas. Contudo, não avança em termos práticos e tampouco estabelece um prazo para que tais políticas sejam implementadas pelos Estados, o que leva a ratificar a ideia de que, mesmo sendo o trabalho decente um princípio e objetivo da Declaração Sociolaboral de 2015, essa diretriz não foi apresentada de forma impositiva aos Estados Partes.

O próximo princípio geral indicado é o das “empresas sustentáveis”, conforme o qual os Estados Partes se comprometem a promover e estimular seis ações que possibilitariam o desenvolvimento sustentável da região. Mais uma vez, a Declaração indica os objetivos a serem buscados, porém não indica aos Estados nenhum prazo para a instituição de tais ações ou tampouco sinaliza quais seriam as medidas necessárias a serem tomadas para a sua implementação.

Outras inovações a serem salientadas são as contidas nos artigos $11^{\circ}$ a $15^{\circ}$, nos quais são elencados alguns dos direitos individuais dos trabalhadores, tais como a limitação de jornada de trabalho, férias e descansos, licenças, remuneração e proteção contra a demissão arbitrária. Observase que, na Declaração de 1998, o texto limita-se a proteger os direitos individuais de forma generalizada, ou seja, os elencados “direitos individuais” não tratavam de particularidades da relação de trabalho, mas sim reiteravam os princípios de não discriminação, igualdade de oportunidades, entre outros, os quais foram mantidos no texto de 2015.

Visualiza-se essa inovação como um passo importante para a aplicação efetiva da Declaração Sociolaboral, haja vista que tais direitos condizem à imposição de limites práticos às condições de trabalho. Ao se estabelecer um limite de jornada não superior a oito horas diárias, como

infantil; (iv) eliminação de todas as formas de discriminação em matéria de emprego e ocupação), a promoção do emprego produtivo e de qualidade, a extensão da proteção social e o fortalecimento do diálogo social” (OIT BRASIL, 1999). 
se verifica no artigo $11^{\circ}$ da Declaração, proporciona-se aos trabalhadores do Mercosul a utilização de tal documento como garantia do direito referido, ainda que o próprio artigo faça referência à “[...] conformidade com as legislações nacionais vigentes nos Estados Partes” (MERCOSUL, 2015). Salienta-se que tais direitos também são originários de Convenções da OIT, logo, assim como na Declaração de 1998, o novo texto optou por incluir no seu articulado os direitos já consagrados pela $\mathrm{OIT}^{12}$.

A respeito da possibilidade de adoção e aplicação da Declaração Sociolaboral pelos ordenamentos jurídicos e tribunais nacionais, tanto na versão de 1998, como na de 2015, verifica-se que isso dependerá da natureza jurídica atribuída pelos Estados ao instrumento referido. Neste artigo, serão analisados dois posicionamentos teóricos diversos, quais sejam: o que entende a Declaração como um instrumento político ideológico, que incentiva os Estados Partes a promoverem os direitos e garantias previstos nesta norma; e outro, que entende a Declaração Sociolaboral como um instrumento do Direito Internacional dos Direitos Humanos. Portanto, no item seguinte, tais entendimentos serão explorados, com o intuito de se analisar qual influência podem exercer na aplicação da Declaração Sociolaboral do Mercosul.

\subsection{NATUREZA JURÍDICA E APLICAÇÃO DA DECLARAÇÃO SOCIOLABORAL DO MERCOSUL}

A Declaração Sociolaboral do Mercosul, desde a versão de 1998, foi alvo de críticas quanto à sua funcionalidade prática. Como afirma Peduzzi (2005, p. 1), a Declaração de 1998 foi fruto de reclamações quanto à ausência de um compromisso social do Mercosul, visto que até aquele momento, os Estados Partes tão somente haviam produzido normas que priorizavam os interesses econômicos do bloco. Nesse sentido, a fim de elucidar a natureza jurídica deste documento, que tem reflexo direto na sua aplicabilidade, serão discutidos, a seguir, dois posicionamentos distintos, que atribuem efeitos jurídicos diferentes à Declaração nos ordenamentos dos Estados Partes e nas decisões dos tribunais internos.

Nesse sentido, a corrente que prevaleceu sobre a natureza jurídica da Declaração Sociolaboral teve por base um modelo jurídico chamado por Santos (1998, p. 336) de "Carta Social politicamente possível”. Santos (1998) esclarece que durante as negociações para a criação dessa

12 Cabe registrar que, no caso do Brasil, o limite da jornada de trabalho diário está previsto na Constituição Federal de 1988, com a seguinte redação: “Art. $7^{\circ}$ São direitos dos trabalhadores urbanos e rurais, além de outros que visem à melhoria de sua condição social: [...] XIII - duração do trabalho normal não superior a oito horas diárias e quarenta e quatro semanais, facultada a compensação de horários e a redução da jornada, mediante acordo ou convenção coletiva de trabalho [...]” (BRASIL, 1988). 
Carta Social foram sugeridos dois modelos jurídicos para serem seguidos: um, teoricamente desejável; e outro, politicamente possível, com características distintas. Assim:

O primeiro, mediante inserção dessa Carta Social em um Protocolo adicional ao Tratado de Assunção, ratificado pelos quatro Estados Partes e automaticamente incorporada aos respectivos ordenamentos, contendo disposições completas, autoexecutáveis, diretamente constitutivas de direitos subjetivos de cada trabalhador e organização profissional; e dotada de um sistema internacional de controle e diretamente aplicável pelos tribunais nacionais. O segundo modelo de carta seria uma mera declaração de objetivos, propósitos ou princípios, sem mecanismos de controle (SANTOS, 1998, p. 336).

A diferença entre os modelos referidos é significativa. Ao se refletir acerca da aplicação desta Declaração, enquanto o primeiro modelo presumiria um cumprimento obrigatório das normas da Declaração Sociolaboral pelos Estados Partes, pelo fato de inseri-las como protocolo adicional ao tratado fundador do Mercosul (portanto, norma de hard law), o segundo modelo - adotado finalmente pelos Estados Partes do Mercosul - apresenta a Declaração Sociolaboral como um indicativo moral de princípios e objetivos a serem alcançados, contudo não impõe aos Estados Partes a obrigatoriedade na sua aplicação, já que se constitui em norma de soft law. Refere ainda Cordeiro (2000), ao analisar os modelos contextualizados por Santos (1998), que a Declaração Sociolaboral do Mercosul foi “[...] forjada sob a ideologia do politicamente possível”, apresentando uma “[...] relação de garantias sociais genéricas sem mecanismos de imposição de seu cumprimento e sem o estabelecimento de órgãos regionais destinados à efetivação dos dispositivos ali relacionados” (CORDEIRO, 2000, p. 141).

Ainda que tal crítica tenha sido lançada à Declaração de 1998, o mesmo raciocínio se aplica à reedição do documento, de 2015, visto que o modelo do politicamente possível foi mantido, ou seja, os direitos e princípios previstos na normativa não estão vinculados ao tratado originário e inexiste um mecanismo de controle previsto na Declaração que imponha o seu cumprimento. Portanto, uma vez que esse requisito não foi alterado na Declaração de 2015, na medida em que segue inexistindo vinculação ao Tratado de Assunção, bem como a criação de um mecanismo de controle, reitera-se a crítica lançada anteriormente, no sentido de que a Declaração Sociolaboral é nada mais que “[...] um documento meramente indicativo, a ter sua aplicação acompanhada por um órgão estritamente promocional, sem conteúdo sancionatório” (CORDEIRO, 2000, p. 141).

Ainda, verifica-se que é necessário que a natureza da norma seja condizente com a cultura da localidade/sociedade à qual se destina. Desse modo, a simples transcrição de princípios e objetivos vinculados a outra realidade que não a do local de destino da norma, também é um fator que prejudica a aplicabilidade dessa norma. Sobre o tema, vale a pena trazer à colação a seguinte reflexão: “De nada serve uma legislação modelada em princípios básicos copiados, por exemplo, de instituições 
europeias, se ela não é cumprida porque não se quer ou não se pode cumprir, já que não corresponde à idiossincrasia local ${ }^{13 ”}$ (SARDEGNA, 1995, p. 39, tradução nossa).

Outro elemento crítico que se aplica a ambas as versões da Declaração Sociolaboral é a “[...] preocupação quase que obsessiva pela preservação dos ordenamentos laborais dos Estados Partes, o que demonstra como o Mercosul está distante de um ordenamento supranacional regulador das relações de trabalho” (CORDEIRO, 2000, p. 141). Essa realidade permaneceu inalterada na Declaração de 2015, em que trechos como “[...] os Estados Partes comprometem-se, conforme a legislação e práticas nacionais” (MERCOSUL, 2015) são a todo momento repetidos nos artigos do documento. Essa disposição também pode ser encarada como algo que limita a aplicação da Declaração Sociolaboral, porque o próprio documento afirma e reafirma a dependência de sua aplicação ao que dispõem as legislações nacionais.

De outro lado, cabe ainda referir o posicionamento acerca da natureza jurídica e aplicabilidade da Declaração Sociolaboral, que destaca seu importante valor político e ético. Sobre o tema, Peña (2014, p. 41-42) faz menção a oito motivos para a sua adoção que, em síntese, estariam vinculados ao fato de que a redação do instrumento compreende compromissos concretos direcionados aos Estados Partes, para que atuem conforme os princípios declarados; portanto, não se trata de um instrumento suscetível de ratificação, ou seja, é imediatamente aplicável. Ademais, prevê ações politicamente possíveis e é um instrumento dinâmico, aberto, flexível e mais facilmente revisto do que um tratado. Prevê um esforço tripartido e regional, está de acordo com os compromissos democráticos do Mercosul e, ainda, possui a ideia de criação de um sistema próprio de solução de controvérsias. Nesse sentido:

A Declaração Sociolaboral do Mercosul, por sua forma, é uma Declaração de Chefes de Estado, e por seu conteúdo, é uma Declaração de direitos sociais. A matéria sociolaboral é parte do direito internacional dos direitos humanos ${ }^{14,15}$, e pertence basicamente aos direitos trabalhistas, bem como aos direitos “civis e políticos”"16 (PEÑA, 2014, p. 42-43, tradução nossa).

13 No original: "De nada sirve una legislación modelo en principios básicos copiados, verbigracia, de institutos europeos, si ella no se cumple porque no se quiere o no se puede cumplir, ya que no se corresponde con la idiosincrasia local”.

14 Cumpre esclarecer que o Direito Internacional dos Direitos Humanos possui um caráter específico e especial que o distingue do Direito Internacional Público, em geral. Nesse sentido, “[...] enquanto este (Direito Internacional Público) busca tradicionalmente disciplinar relações de reciprocidade e equilíbrio entre Estados, por meio de negociações e concessões recíprocas que visam ao interesse dos próprios Estados pactuantes, o Direito Internacional dos Direitos Humanos objetiva garantir o exercício dos direitos da pessoa humana” (PIOVESAN, 2016, p. 85).

15 Já o Direito Internacional, em seu sentido específico de international law, “[...] emergiu, principalmente a partir da segunda metade do século XIX, como um sistema jurídico essencialmente europeu imbuído, politicamente, de uma certa missão civilizadora. As normas jurídicas e os instrumentos teóricos derivados desse sistema serviram de ferramentas úteis a propósitos históricos, colonializantes, e carregavam em si a contradição fundamental que opunha povos civilizados e não civilizados” (DAL RI JÚNIOR; BIAZI; ZIMMERMANN, 2017, p. 62).

16 No original: “La Declaración Sociolaboral del Mercosur, por su forma es una Declaración de Jefes de Estado, y por 
Por este raciocínio, Peña (2014, p. 43) defende que a Declaração Sociolaboral do Mercosul constitui um instrumento internacional sobre direitos humanos e, portanto, seus efeitos superariam os de uma simples declaração, ou seja, os direitos previstos na Declaração Sociolaboral do Mercosul independeriam de legislação nacional para sua implementação, e seriam vinculantes, porque possuem sua própria eficácia jurídica, haja vista que uma vez recepcionados pelos Estados Partes passam a integrar o ordenamento jurídico nacional.

Para justificar esta afirmação, Peña (2014, p. 43-48) analisa os efeitos jurídicos de uma declaração internacional de direitos humanos, com base no exemplo da Declaração Universal dos Direitos Humanos (DUDH) de 1948, da ONU. A autora refere que até 1971, o entendimento era de que, ainda para os Estados que haviam votado a favor da DUDH, essa serviria apenas como inspiração, não possuindo efeito vinculante algum. Contudo, com o passar do tempo, a DUDH adquiriu outro caráter, sendo reconhecida como um instrumento solene que supera a simples expressão de ideias, tendo expandido seus efeitos jurídicos. Assim, a eficácia jurídica da DUDH passa a ser reflexiva, pois deriva de uma fonte de direito internacional prevista no Estatuto da Corte Internacional de Justiça, que, nesse caso especial, seria representada pelo artigo 56 da Carta das Nações Unidas ${ }^{17}$, referente à operação internacional para a promoção dos direitos humanos e o respeito a eles.

O mesmo raciocínio pode ser empregado à Declaração Sociolaboral do Mercosul, considerando que os Estados Partes reconhecem no preâmbulo desse documento, de forma voluntária e implícita, que a sua eficácia jurídica vai além de compromissos éticos e políticos, bem como reconhecem seu compromisso em respeitar e promover os direitos e obrigações previstos nesse instrumento. Logo, sua aplicabilidade seria imediata, haja vista sua natureza de instrumento de Direito Internacional de Direitos Humanos ${ }^{18}$, conforme conclui a autora:

Estas expressões serviram para que grande parte da doutrina reconheça o caráter vinculante e obrigatório deste instrumento, a margem de ser uma declaração não suscetível de ratificação, especialmente por consagrar direitos fundamentais que integram o patrimônio

su contenido, es una Declaración de derechos sociales. La materia sociolaboral es parte del derecho internacional de los derechos humanos, y pertenece básicamente a los derechos laborales como a los derechos “civiles y políticos’”.

17 "Para a realização dos propósitos enumerados no Artigo 55, todos os Membros da Organização se comprometem a agir em cooperação com esta, em conjunto ou separadamente” (BRASIL, 1945).

18 Cumpre referir a pesquisa publicada por Rodrigues de Souza e Alvares Gaspar (2016), na qual corroboram a premissa que a Declaração Sociolaboral avoca a condição de instrumento internacional de direitos humanos perante a jurisdição dos Estados Partes, já que “[...] as Constituições mercosulinas contêm cláusulas constitucionais abertas que permitem a integração entre a ordem constitucional e a ordem internacional no campo dos direitos humanos, ampliando e expandindo o bloco de constitucionalidade”. 
jurídico da humanidade. Posição que compartilho plenamente, ao redor da qual gira esta tese, com a pretensão de sua justificação ${ }^{19}$ (PEÑA, 2014, p. 48, tradução nossa).

A recepção da Declaração Sociolaboral do Mercosul enquanto instrumento de direitos humanos condiz com a visão de Ermida Uriarte acerca do caráter progressivo e aberto desse instrumento, pois uma vez recepcionada pelos Estados Partes, estes confirmam que os diplomas internacionais de direitos humanos que dão base aos princípios e direitos expostos na Declaração são compatíveis com os seus ordenamentos jurídicos, conforme se verifica nas seguintes considerações:

Do mesmo modo, a recepção dos grandes Pactos e Declaraçães de direitos humanos "que
integram o patrimônio jurídico da humanidade”, com os quais “os Estados Partes estão
comprometidos” e com os quais a Declaração está alinhada, poderia sustentar que os direitos
e princípios contidos na Declaração - juntamente com aqueles - são obrigatórios, vinculantes
e de plena eficácia jurídica, seja pela própria natureza da Declaração e pela superioridade do
direito internacional, seja porque fazem parte do ius cogens, isso é, do corpo de direitos
humanos básicos que constituem a ordem pública internacional, em adição a qualquer ato de
reconhecimento, ratificação ou recepção pelos sistemas jurídicos nacionais ${ }^{20}$. (ERMIDA
URIARTE, 2003, p. 248-249, tradução nossa).

Nesse sentido, a classificação da Declaração Sociolaboral do Mercosul como instrumento do Direito Internacional dos Direitos Humanos seria suficiente para elidir as primeiras críticas apresentadas no tocante à sua aplicabilidade, visto que supriria a necessidade de tornar a Declaração um anexo do Tratado de Assunção, pois sua aplicação obrigatória já se conferira diante dessa natureza jurídica de instrumento de direitos humanos.

Por fim, ao refletir sobre as críticas lançadas ao documento de 1998, a Declaração de 2015 superou sua antecessora no tocante à indicação de direitos individuais referentes às relações contratuais de trabalho, visto que indicou expressamente, em seus artigos $11^{\circ}$ a $15^{\circ}$, a proteção do trabalhador quanto ao limite de jornada diário e a existência do direito de férias, entre outras garantias. Essa previsão possibilita uma maior aplicação do texto da Declaração de 2015, no momento de solucionar conflitos trabalhistas, os quais serão alvo de análise no próximo tópico, restringindo-se às reclamatórias julgadas pelo TAL até 30 de agosto de 2020 e publicadas no site do TPR, com o intuito

19 No original: "Estas expresiones sirvieron para que gran parte de la doctrina reconozca el carácter vinculante y obligatorio de este instrumento, al margen de ser una declaración no susceptible de ratificación, especialmente por consagrar derechos fundamentales que integran el patrimonio jurídico de la humanidad. Posición que comparto plenamente, alrededor de la cual gira esta tesis, con la pretensión de su justificación”.

20 No original: “Asimismo, si se atiende a su recepción de los grandes Pactos y Declaraciones de Derechos Humanos 'que integran el patrimonio jurídico de la humanidad', con los cuales 'los Estados partes están comprometidos' y con los cuales la Declaración se alinea, podría llegar a sostenerse que los derechos y principios contenidos en la Declaración -junto con aquéllos- son obligatorios, vinculantes y de eficacia jurídica plena, sea por el propio carácter de la Declaración y la superioridad de ordenamiento internacional, sea porque formen parte del ius cogens, esto es, del cuerpo de derechos humanos básicos que constituyen el orden público internacional, más allá de todo acto de reconocimiento, ratificación o recepción por los ordenamientos jurídicos nacionales”. 
de se verificar se a Declaração Sociolaboral é utilizada como norma de base para a solução dos conflitos.

\title{
2 ANÁLISE DAS DECISÕES DO TRIBUNAL ADMINISTRATIVO TRABALHISTA DO MERCOSUL (TAL) SOB A PERSPECTIVA DA APLICAÇÃO DA DECLARAÇÃO SOCIOLABORAL
}

O TAL corresponde à única instância jurisdicional para a solução de reclamações do tipo administrativo-laboral dos funcionários do Mercosul $^{21}$ e dos funcionários contratados, pelos órgãos do bloco, para a realização de obras e serviços específicos. Conforme disposições inseridas em seu documento de origem, a Resolução n ${ }^{\circ}$ 54/03, e em informações presentes no site oficial do TPR, o TAL é formado por “1 Membro Titular e 1 Membro Suplente indicados por cada um dos Estados Partes, e são designados pelo GMC pelo período de dois anos, renováveis por igual período. As decisões pronunciadas pelo TAL são de caráter definitivo e não apelável”. Sobre o escopo da criação do tribunal referido, pode-se sustentar que:

\begin{abstract}
Os tribunais administrativos trabalhistas das organizações internacionais consistem em um mecanismo jurisdicional (que tende a alcançar certa independência) para resolver disputas relativas a funcionários e empregados que trabalham em organizações internacionais e fornecem uma solução (alternativa, em relação à função judicial) a conflitos internos que possam surgir em matéria de trabalho (emprego público internacional). A finalidade desses tribunais, além de resolver o conflito, é que os funcionários, contratados e funcionários da organização internacional considerem desnecessário recorrer a processos judiciais nos Estados Membros ou no país sede da organização em busca de uma solução para o conflito. [...] Além disso, há outra vertente jurídica segundo a qual os conflitos trabalhistas das estruturas institucionais nascidas nos sistemas comunitários são resolvidos pelos tribunais judiciais criados a partir da lei comunitária ou da união ${ }^{22}$. (SUÑÉ, 2017, p. 104, tradução nossa).
\end{abstract}

Especificamente quanto ao TAL, a análise partirá de seu documento de origem, a Resolução $n^{\circ}$ 5/03, do GMC, que é composta por três considerações iniciais e três artigos, nos quais se verificam

21 A título informativo, na União Europeia, foi criado o Tribunal da Função Pública, em 2004, responsável pelo julgamento das demandas promovidas pelos funcionários do bloco. Em 2016, o Tribunal referido foi dissolvido e as funções por ele exercidas foram assumidas pelo Tribunal Geral, estrutura que juntamente com o Tribunal de Justiça da União Europeia integra o sistema judicial comunitário europeu. (TRIBUNAL DE JUSTIÇA DA UNIÃO EUROPEIA, 2020).

22 No original: "Los tribunales administrativos laborales de las organizaciones internacionales consisten en un mecanismo jurisdiccional (que tienden a lograr una cierta independencia) para resolver las disputas concernientes a los funcionarios y empleados que se desempeñan en organizaciones internacionales y proporcionar una solución (alternativa, en relación a la función judicial) a conflictos internos que se puedan suscitar en materia laboral (empleo público internacional). La finalidad de los mismos, además de dirimir el conflicto, consiste en que los empleados, contratados y funcionarios de la propia organización internacional consideren innecesario recurrir a procesos judiciales en los Estados miembros o del país sede de la organización en busca de una solución al conflicto. [...] Además de ellos, existe otra vertiente jurídica según la cual los conflictos laborales de las estructuras institucionales nacidas en los sistemas comunitarios sean resueltos por los tribunales judiciales creados a partir del derecho comunitario o de la unión”. 
os elementos que justificaram a criação do TAL, bem como as bases normativas para a fundação desse tribunal, sendo elas: o Tratado de Assunção, o Protocolo de Ouro Preto, as Decisões de n 4/96 e 30/02 do Conselho Mercado Comum (CMC) e as Resoluções nº 42/97 e 01/03 do GMC ${ }^{23}$. Ainda, integrada à Resolução no 54/03, está um anexo intitulado "Estatuto do Tribunal Administrativo Trabalhista do Mercosul”, contendo 16 artigos nos quais são previstas todas as atividades, competências e regras aplicáveis ao Tribunal. Todavia, antes mesmo desse anexo, observam-se, nos três primeiros artigos, algumas características importantes:

Art. 1 - Criar o "Tribunal Administrativo-Trabalhista do MERCOSUL”, única instância jurisdicional para resolver as reclamações de índole administrativa-trabalhista do pessoal da $\mathrm{SM}^{24}$ e as pessoas contratadas pela SM para obras ou serviços determinados na SM e em outros órgãos da estrutura Instituicional [sic] do MERCOSUL.

Art. 2 - A atuação do Tribunal Administrativo-Trabalhista do MERCOSUL reger-se-á pelo Estatuto que figura em Anexo e que forma parte da presente Resolução.

Art. 3 - Esta Resolução não necessita ser incorporada ao ordenamento jurídico dos Estados Partes, por regulamentar aspectos de organização e funcionamento do MERCOSUL (TAL MERCOSUL, 2003, grifo nosso).

A atuação restrita do TAL na solução de controvérsias dos trabalhadores que prestam serviços diretos ao Mercosul é claramente estabelecida no trecho citado, visto que se indica que a SM será a instituição empregadora desses trabalhadores.

Pois bem, disso resultam as seguintes indagações: os funcionários ou prestadores de serviço do Mercosul terão suas reclamatórias trabalhistas julgadas exclusivamente pelo TAL, com base em que tipo de legislação? Aplica-se, ao caso, a legislação do Mercosul, especificamente a Declaração Sociolaboral, ou se aplica a legislação interna do Estado onde foi prestado o serviço? E as normativas internacionais, como as declarações e convenções que garantem direitos aos trabalhadores, serão consideradas pelo TAL nesses julgamentos, especificamente aquelas provenientes da OIT, considerando que os Estados Partes do Mercosul são signatários da maioria dessas normas?

Esses questionamentos são respondidos pelo artigo $3^{\circ}$ do anexo da Resolução $n^{0} 54 / 03$, que se refere a três tipos de regras aplicáveis: “[...] normas do Acordo de Sede (Decisão CMC nº 04/96), as normas MERCOSUL aplicáveis ao pessoal da SM e as Instruções de Serviço ditadas pelo Diretor da SM” (TAL MERCOSUL, 2003).

23 Cabe esclarecer o conteúdo das normativas mercosulinas referidas: Tratado de Assunção de 1991 é o tratado por meio do qual foi criado o Mercosul; Protocolo de Ouro Preto de 1994 é um adicional ao Tratado de Assunção sobre a Estrutura Institucional do Mercosul; Decisões nº 4/96 e 30/02 do CMC definem a sede do bloco no Uruguai e regulam a estrutura da Secretaria Administrativa do Mercosul; e as Resoluções no 42/97 e 01/03 do GMC definem a estrutura e funcionamento da Secretaria do Mercosul e as normas gerais aplicáveis aos seus funcionários (MERCOSUL, 2020).

24 “SM" é a sigla correspondente à "Secretaria do MERCOSUL”, conforme informação presente no artigo $1^{\circ}$ do anexo da Resolução n 54/03 (TAL MERCOSUL, 2003). 
À primeira vista, do conteúdo expresso no artigo $3^{\circ}$ da Resolução n ${ }^{\circ}$ 54/03 é possível refletir que o TAL se valeria somente das regras antes sinalizadas para a solução de tais demandas, uma espécie própria ou específica de direito do trabalho, relativo exclusivamente aos funcionários do Mercosul. Está equivocada, entretanto, tal visão, pois ainda que os funcionários do Mercosul possuam uma legislação regulamentadora própria, esses trabalhadores são alcançados pelas normas reconhecidas pelo bloco como patrimônio jurídico da humanidade, ou seja, todas aquelas declarações e pactos sinalizados no preâmbulo da Declaração Sociolaboral do Mercosul, e, por consequência, todos os direitos e princípios nela previstos. Essa afirmação é comprovada pela análise do conteúdo das sentenças produzidas pelo TAL, conforme se verá à continuação.

Assim, com base no entendimento de que a Declaração Sociolaboral do Mercosul está inserida no rol de regras aplicáveis aos julgamentos do TAL, passa-se à análise das quatro decisões publicadas pelo TAL até a data-limite desta pesquisa (30 de agosto de 2020), com o intuito de vislumbrar se tanto os trabalhadores requerem a aplicação dessa normativa, quanto os julgadores de fato aplicam a Declaração Sociolaboral como norma especial, ainda que de soft law, para a solução de conflitos trabalhistas dos funcionários do Mercosul.

A análise das sentenças abaixo será realizada de forma individual, à exceção dos dois primeiros casos, destacando-se os fatos e pedidos de cada reclamatória e principalmente o direito aplicável ao caso. Assim, cumpre salientar que das quatro decisões publicadas pelo TAL e disponibilizadas em site oficial, as primeiras foram julgadas na vigência da Declaração Sociolaboral de 1998 e as últimas duas já conforme a reedição de 2015 (TAL MERCOSUL, 2020).

\subsection{SENTENÇAS PUBLICADAS EM 23/09/2005 PELO TRIBUNAL ADMINISTRATIVO TRABALHISTA DO MERCOSUL}

As primeiras sentenças que serão objeto de análise foram publicadas em 23/09/2005 e, ainda que sejam relacionadas a processos individuais, serão analisadas de forma conjunta, por se tratar de ações que versaram sobre os mesmos pedidos e obtiveram o mesmo julgamento.

Os autores das reclamatórias, a Sr. ${ }^{a}$ Maureen Margaret Mackinnon Gómez e o Sr. Raulino Carvalho de Oliveira, foram funcionários da Secretaria Administrativa do Mercosul, a qual configura como reclamada em ambas as ações. Os pedidos postulados nas reclamatórias foram o pagamento de indenização por dispensa, horas extras, salário, férias e danos e prejuízos. No tocante aos dispositivos legais utilizados como embasamento dos pedidos referidos, os reclamantes indicaram as normas do 
Mercosul e a norma laboral uruguaia ${ }^{25}$, para justificar o pedido de indenização por dispensa, e também fundamentaram seus pedidos no disposto em tratados internacionais, convenções da OIT, Convenção Interamericana de Direitos Humanos e Resoluções do GMC de ${ }^{\text {os }} 42 / 97,1 / 03$ e 54/03, extrapolando o âmbito da normativa mercosulina.

A reclamada afirma, em sua contestação, que a relação que vincula as partes não constitui um contrato de trabalho típico, sendo este similar a um contrato de função pública, em que as instituições de Direito Público se regem por regras e princípios próprios, diferentes daqueles que regulam um contrato de trabalho privado. E, por consequência, não seriam aplicáveis os princípios de Direito do Trabalho citados pelos reclamantes.

O TAL, ao iniciar a análise do caso, apresenta questões prévias que entende pertinentes à solução da demanda, sendo essas: a) constituição e competências do TAL; b) direito aplicável; c) legitimidade ativa; d) prescrição; e) instância administrativa prévia. Pelo objetivo pretendido neste artigo, concentrar-se-á a análise na questão prévia acerca do direito aplicável, sendo de significativa importância para o presente estudo o disposto nessas sentenças.

Ao indicar o artigo $3^{\circ}$ do Estatuto do TAL, anexo à Resolução $n^{0} 54 / 03$, os julgadores afirmam que os fundamentos jurídicos das sentenças serão compostos por aquelas normas previstas nesse artigo e, somando a essas, as normas gerais e regramentos ditados pelos órgãos do Mercosul, assim como os princípios gerais de direito. Referem, ainda, que diante da inclusão de princípios gerais de direito é necessária a determinação de quais são os princípios aplicáveis ao caso, levando em consideração o fato de que são relações regidas por normas específicas, próprias do Mercosul, concluindo que

\begin{abstract}
A critério do TAL, são aplicáveis ao caso os princípios gerais de direito proclamados nos instrumentos internacionais e regionais que consagram direitos de mais alto valor e eficácia que se consideram essenciais à consciência jurídica universal, assim como resultantes do estudo do Direito Comparado dos quatro Estados Partes do Mercosul. Nesse sentido, e atendendo à especificidade do caso, resulta evidente que são aplicáveis os princípios enunciados nas convenções internacionais do trabalho, na Declaração dos Princípios e Direitos Fundamentais da OIT e na Declaração Sociolaboral do Mercosul (TAL MERCOSUL, 2005, p. 7-8, tradução nossa, grifo nosso).
\end{abstract}

Logo, ainda que os reclamantes não tenham requerido de forma expressa o reconhecimento da Declaração Sociolaboral do Mercosul como norma aplicável à solução de sua demanda, o Tribunal reconheceu que essa normativa atendia à especificidade do caso e, portanto, seria aplicável.

25 Cabe referir que a indicação do direito uruguaio decorre do fato de que a sede da SM está em Montevidéu, lugar onde ocorreu a prestação de serviço (TAL MERCOSUL, 2020). 
Sobre o tema, ressaltam-se dois aspectos que merecem ponderação: o primeiro, refere-se ao fato de os reclamantes não terem indicado de forma expressa a Declaração Sociolaboral como norma aplicável, demonstrando tratar-se de uma negligência, descaso ou desconhecimento, uma vez que a norma foi aprovada em 1998 e regula os princípios e direitos aplicáveis aos contratos de trabalho, prescrevendo aos trabalhadores do bloco uma série de garantias; e o segundo, o reconhecimento expresso nessas primeiras sentenças publicadas pelo TAL, em 2005, acerca da aplicação da Declaração nas demandas trabalhistas dos funcionários do Mercosul, que, ainda que estejam regulados por uma legislação própria, fazem jus aos direitos e garantias previstos nas normativas internacionais e regionais que regulam o Direito do Trabalho, atribuindo, desta forma, força cogente à Declaração, no que há interesse.

O resultado das sentenças foi a procedência parcial da demanda, com a condenação da reclamada ao pagamento de indenização pela dispensa dos reclamantes, tendo o TAL considerado como fundamentos os artigos de normas do Mercosul, como a Resolução nº 42/97 do GMC, mas também os princípios gerais aceitos pela doutrina e jurisprudência dos Estados Partes, sendo eles princípio in dubio pro operario e princípio da norma mais favorável (TAL MERCOSUL, 2005).

Em relação aos pedidos que foram julgados improcedentes, o TAL justificou a inadequação do direito requerido pelos autores, como no caso do pedido de salário de férias. Para esse mesmo pedido, foi também indicado como argumento o fato de inexistir qualquer trato discriminatório aos reclamantes, podendo-se considerar que os julgadores se basearam no princípio da não discriminação, presente na Declaração Sociolaboral e nas convenções da $\mathrm{OIT}^{26}$, ainda que não tenham feito referência ao princípio ou à Declaração de forma expressa.

Contudo, em toda a fundamentação jurídica, o Tribunal não se manifestou expressamente sobre a aplicação da Declaração Sociolaboral a justificar a procedência ou não de alguns dos pedidos dos reclamantes, mesmo tendo reconhecido essa normativa como aplicável ao caso.

\subsection{SENTENÇA PUBLICADA EM 10/12/2015 PELO TRIBUNAL ADMINISTRATIVO TRABALHISTA DO MERCOSUL}

Em ação promovida pela Sr. ${ }^{a}$ María Del Carmen García contra o Instituto Social do Mercosul (ISM), a reclamante requereu a reintegração ao seu trabalho, invocando a normativa do Mercosul, que “[...] no seu entender, não foi respeitada pelo ISM” (TAL MERCOSUL, 2015). A reclamada, ao

26 O princípio da não discriminação está previsto na Convenção da OIT no 111, cujo título é “Discriminação em Matéria de Emprego e ocupação”, ratificada pelo Brasil em 26/11/1965 (BRASIL, 2019). 
apresentar resposta, não se considerou capaz de contestar os pedidos, visto que o responsável pelo ISM quando da vigência do contrato da reclamante não estaria mais atuando na instituição.

Referente ao direito aplicável ao caso, o Tribunal reiterou os fundamentos apresentados nas sentenças anteriores quando, citando o texto do artigo $3^{\circ}$ da Resolução $n^{\circ}$ 54/03, considerou como regras aplicáveis aquelas expressamente citadas e, ainda, os “[...] princípios gerais de direito proclamados em instrumentos internacionais e regionais” (TAL MERCOSUL, 2015), entre os quais se encontra a Declaração Sociolaboral do Mercosul.

Novamente, vislumbra-se a ausência de requerimento expresso pela reclamante para a aplicação da Declaração Sociolaboral, limitando-se a referir, em sua argumentação, a existência de violação às normas do Mercosul. Ausente, também, a aplicação da Declaração por parte do Tribunal, pois ainda que tivesse reconhecido a aplicação dessa norma ao caso em apreço, não a utilizou para justificar a procedência da demanda.

A respeito dos argumentos legais utilizados na sentença, nota-se um certo apego do TAL à utilização de determinados princípios gerais do direito, mas sem ressaltar o conteúdo da Declaração Sociolaboral, como neste caso, em que o Tribunal se vale tão somente do princípio iura novit curia, esclarecendo ser dever do juiz, enquanto conhecedor do direito, “decidir conforme as normas legais, ainda quando as partes não tenham fundamentado corretamente sua petição” (TAL MERCOSUL, 2015).

\subsection{SENTENÇA PUBLICADA EM 23/10/2017 PELO TRIBUNAL ADMINISTRATIVO TRABALHISTA DO MERCOSUL}

A última decisão analisada foi proposta pelo Sr. Luís Flores contra o Parlamento do Mercosul (PARLASUL), com pedido de reintegração a seu posto de trabalho, somado ao pagamento de salários e recolhimento das contribuições cabíveis até a efetiva reintegração, e, em caso de indeferimento da reintegração, o pagamento de quantia indenizatória pela demissão arbitrária. Em sua petição, o reclamante indica como argumentos jurídicos as jurisprudências administrativas norteamericana e uruguaia, referentes à ação arbitrária e ilegal, bem como invoca normas que a seu critério foram descumpridas, a saber: “Constituição e leis nacionais uruguaias²7, Convenção Internacional de

27 Cabe destacar que a referência à aplicação do direito uruguaio se deve a que a sede do PARLASUL está em Montevidéu, lugar da prestação do trabalho (TAL MERCOSUL, 2017). 
Trabalho da OIT, Declaração Sociolaboral do Mercosul, Decisão 07/07 do CMC e o Protocolo Constitutivo do PARLASUL” (TAL MERCOSUL, 2017).

Ao contestar a demanda, o PARLASUL sustentou que “[...] nestes autos não cabe aplicar normas nacionais dos Estados Partes, sendo incorretas as citações da Constituição e leis uruguaias que realiza o reclamante” (TAL MERCOSUL, 2017), uma vez que o PARLASUL teria estatuto próprio com regime equivalente ao do pessoal da Secretaria do Mercosul, mas que, na época, ainda não havia sido editado.

Ante tais considerações, o TAL deveria enfrentar, antes mesmo de decidir o mérito do pedido, qual a legislação aplicável ante a ausência de um estatuto próprio à relação de trabalho entre o PARLASUL e o reclamante. Decidiu, então, o Tribunal, novamente com base no artigo $3^{\circ}$ da Resolução $n^{\circ}$ 54/03, pela legítima aplicação dos princípios gerais do direito provenientes de instrumento internacionais e regionais, incluindo a Declaração Sociolaboral do Mercosul. Entendeu, todavia, serem inaplicáveis as normas nacionais de qualquer Estado Parte do Mercosul, tampouco sendo aplicável a jurisprudência do Uruguai ou de países fora do Mercosul, como citado pelo reclamante.

Referente à inexistência de estatuto próprio do PARLASUL, o Tribunal considerou que não seria possível aplicar por analogia as normas que regem os funcionários do Mercosul, por considerar diversa a natureza do funcionário do PARLASUL e, também, porque esses funcionários não ingressam por concurso público internacional, como ocorre com os demais funcionários do bloco. Assim, a fundamentação legal utilizada, a fim de justificar a improcedência da ação, foi com base nas normas estabelecidas entre as partes para a relação contratual (TAL MERCOSUL, 2017).

Ademais, destaca-se que o TAL não fez uso, no julgamento desta reclamatória, de nenhum princípio ou referência específica a direito previsto na Declaração Sociolaboral, restringindo-se a indicar a inexistência de “[...] perseguição ou discriminação alegada pelo reclamante” (TAL MERCOSUL, 2017), contudo sem utilizar nenhuma referência ao princípio da não discriminação, previsto de forma expressa na Declaração.

Assim, ainda que se tenha verificado um avanço nesta reclamatória, pelo requerimento do autor acerca da aplicação da Declaração Sociolaboral, o mesmo não ocorreu com a postura do TAL, pois tampouco citaram-se os princípios e direitos previstos na Declaração, enquanto fundamentos para a improcedência da demanda, ainda que tenha havido uma vaga referência à norma em comento. 


\section{CONSIDERAÇÕES FINAIS}

A Declaração Sociolaboral do Mercosul, tanto em sua primeira versão, de 1998, quanto na reedição de 2015, não se mostrou um documento inovador acerca do conteúdo material apresentado, visto que os direitos e garantias elencados são os mesmos previstos em convenções da OIT e em outros instrumentos internacionais de direitos humanos. Entretanto, a sua criação e reconhecimento pelos Estados Partes do Mercosul é o que merece ser exaltado, enquanto diferencial inovador, pois ainda que o bloco econômico tivesse promovido discussões em subgrupos de trabalho acerca das questões sociais e trabalhistas, foi mediante essa declaração que maiores amparos legais foram estendidos aos trabalhadores, corroborando direitos e garantias já previstos nos instrumentos globais referidos, agora reiterados no âmbito regional.

Desse modo, as críticas podem ser concentradas à forma como a Declaração Sociolaboral foi aprovada, no âmbito do Mercosul, como norma de soft law, desprovida de força vinculante, o que termina refletindo em como ela tem sido aplicada nas demandas práticas dos trabalhadores. Em razão do exposto, optou-se, neste artigo, por analisar como a Declaração Sociolaboral é aplicada na solução de reclamatórias trabalhistas patrocinadas por funcionários do Mercosul, e consequentemente, como tais demandas vem sendo julgadas pelo TAL.

Da análise do conteúdo das quatro sentenças julgadas pelo TAL até a data limite da pesquisa, ou seja, 30 de agosto de 2020, pode-se verificar que ainda que o Tribunal reconheça a aplicação da Declaração Sociolaboral na solução das reclamatórias trabalhistas dos funcionários do Mercosul, o que por si só é um avanço, não a refere como fundamento jurídico para as suas decisões, sendo silente quanto aos direitos e garantias previstos na norma, ainda que seu conteúdo esteja em total conformidade com os pedidos das reclamatórias. Outro fator que também desperta interesse é a ausência de requerimento por parte dos reclamantes para a aplicação da Declaração Sociolaboral, pois nos quatro casos analisados, somente em um deles o reclamante indicou a violação de direitos contidos na norma em comento. Em razão do exposto, a hipótese de trabalho referida ao começo deste artigo não se confirmou em sua totalidade, na medida em que a Declaração Sociolaboral foi utilizada pelo TAL, ainda que de forma insatisfatória, como antes referido.

Disso, conclui-se que a aplicação da Declaração Sociolaboral do Mercosul é de responsabilidade tanto dos trabalhadores quanto dos tribunais e dos Estados Partes do Mercosul. Os trabalhadores têm o dever de postular em suas demandas trabalhistas a aplicação da Declaração, pois, do contrário, não provocarão os tribunais a aplicarem os direitos e princípios previstos na norma. Por sua vez, os tribunais têm o dever de analisar e aplicar o direito, mesmo que os reclamantes não o 
postulem, conforme o princípio iura novit curia, citado na terceira decisão analisada. Ademais, como reconhecido nas decisões do próprio TAL, a Declaração Sociolaboral compreende o rol de documentos regionais que protegem direitos essenciais dos trabalhadores.

E, por fim, cabe resgatar que os Estados Partes se comprometeram, no momento da criação da Declaração, em integrar e aplicar em suas legislações nacionais o conteúdo da norma referida, bem como em promover ações práticas a fim de se alcançar os objetivos propostos em seu texto, ao que se soma o fato de que o Protocolo de Ouro Preto, tratado ratificado por todos os Estados Partes do bloco, determina, no seu art. 38, que os Estados devem se comprometer em adotar todas as medidas necessárias para assegurar, em seus respectivos territórios, o cumprimento das normas emanadas dos órgãos do Mercosul (MERCOSUL, 1994).

Logo, o compromisso com a aplicação da Declaração Sociolaboral do Mercosul supera os limites das ações individuais, pois os princípios e direitos previstos em seu documento procuram garantir a todos os trabalhadores melhores condições de trabalho, e, por conseguinte, o desenvolvimento econômico e social dos Estados Partes, razão pela qual a Declaração merece receber um tratamento distinto, para converter-se finalmente em norma de efetiva aplicação.

\section{REFERÊNCIAS}

BORREGO, Neiza Salazae. Los actores sociales en el Mercosur. Una mirada hacia la participación en las relaciones de trabajo. Revista de Filosofia Jurídica, social y política - FRONESIS, [s. l.], v. 17, n. 3, p. 399-423, 2010.

BRASIL. Constituição da República Federativa do Brasil de 1988. Brasília, DF: Presidência da República, 1988. Disponível em: https://bit.ly/3lCdwHZ. Acesso em: 26 ago. 2020.

BRASIL. Decreto $\mathbf{n}^{\mathbf{0}} \mathbf{1 0 . 0 8 8}$, de 5 de novembro de 2019. Consolida atos normativos editados pelo Poder Executivo Federal que dispõem sobre a promulgação de convenções e recomendações da Organização Internacional do Trabalho - OIT ratificadas pela República Federativa do Brasil. Brasília, DF: Presidência da República, 2019. Disponível em: https://bit.ly/3okRefI. Acesso em: 26 ago. 2020.

BRASIL. Decreto $\mathbf{n}^{\mathbf{0}} \mathbf{1 9 . 8 4 1}$, de 22 de outubro de 1945. Promulga a Carta das Nações Unidas, da qual faz parte integrante o anexo Estatuto da Corte Internacional de Justiça, assinada em São Francisco, a 26 de junho de 1945, por ocasião da Conferência de Organização Internacional das Nações Unidas. Brasília, DF: Presidência da República, 1945. Disponível em: https://bit.ly/37yUzkm. Acesso em: 26 ago. 2020.

BRASIL. Decreto n ${ }^{0}$ 5.722, de 13 de março de 2006. Promulga o Acordo Multilateral de Seguridade Social do Mercado Comum do Sul e seu Regulamento Administrativo, de 15 de 
dezembro de 1997. Brasília, DF: Presidência da República, 2006. Disponível em: https://bit.ly/2KZf6H7. Acesso em: 26 ago. 2020.

CORDEIRO, Wolney de Macedo. A regulamentação das relações de trabalho individuais e coletivas no âmbito do Mercosul. São Paulo: LTr, 2000.

DAL RI JÚNIOR, Arno; BIAZI, Chiara Antonia Sofia Mafrica; ZIMMERMANN, Taciano Scheidt. O direito internacional e as abordagens do "Terceiro Mundo": contribuições da teoria crítica do direito. Revista da Faculdade de Direito UFPR, Curitiba, v. 62, n. 1, p. 61-81, jan./abr. 2017. ISSN 2236-7284. Disponível em: https://revistas.ufpr.br/direito/article/view/47216. Acesso em: 5 out. 2018.

DRI, Clarissa Franzoi. Políticas públicas regionais: uma análise da regulação de direitos sociais no Mercosul. Revista Espaço Jurídico, Joaçaba, v. 11, n. 1, p. 187-216, jan./jun. 2010. Disponível em: https://bit.ly/3g3GjEf. Acesso em: 24 jul. 2018.

ERMIDA URIARTE, Oscar. La Declaración Sociolaboral del Mercosur y su eficacia jurídica. Revista IUS ET VERITAS, [s. l.], v. 13, n. 27, p. 247-258, 2003.

FEFERBAUM, Marina. Comunidades econômicas na proteção aos direitos humanos: desafios e perspectivas de uma agenda de direitos humanos na integração regional. Revista da Faculdade de Direito UFPR, Curitiba, v. 62, n. 1, p. 155-182, jan./abr. 2017. ISSN 2236-7284. Disponível em: https://revistas.ufpr.br/direito/article/view/48004. Acesso em: 5 out. 2018.

GARCIA JÚNIOR, Armando Alvares. O Direito do Trabalho no Mercosul. São Paulo: LTr, 1997.

MERCOSUL. Declaração Sociolaboral do Mercosul de 1998. Disponível em: https://bit.ly/36z1L0H. Acesso em: 24 ago. 2020.

MERCOSUL. Declaração Sociolaboral do Mercosul de 2015. Disponível em: https://bit.ly/2VLyhGR. Acesso em: 24 ago. 2020.

MERCOSUL. Gestor de documentos. 2020. Disponível em: https://bit.ly/3mGCOpy. Acesso em: 26 ago. 2020.

MERCOSUL. Protocolo Adicional ao Tratado de Assunção sobre a Estrutura Institucional do Mercosul 17 de dezembro de 1994 - Ouro Preto. 1994. Disponível em: https://bit.ly/2VzjUFm. Acesso em: 26 ago. 2020.

MERCOSUL. Resolução no 11/1991. Disponível em: https://bit.ly/36BXGZH. Acesso em: 6 out. 2018.

NORRIS, Roberto. Contratos Coletivos Supranacionais de Trabalho e a Internacionalização das Relações Laborais no Mercosul. São Paulo: LTR, 1998.

OIT BRASIL. Trabalho Decente. Brasília, DF: OIT, 1999. Disponível em: https://bit.ly/39DtM9b. Acesso em: 26 ago. 2020. 
ONU BRASIL. Objetivos de Desenvolvimento Sustentável. Transformando Nosso Mundo: A Agenda 2030 para o Desenvolvimento Sustentável. [S. l.]: ONU Brasil, 2015. Disponível em: https://bit.ly/3lE3MwI. Acesso em: 26 ago. 2020.

PEDUZZI, Maria Cristina Irigoyen. Aplicabilidade da Declaração Sociolaboral do Mercosul nos Estados-Partes. In: Encontro de Cortes Supremas do Mercosul, 3, 2005, Brasília. Resumos. Brasília, 22 nov. 2005, p. 1-9. Disponível em: https://bit.ly/3g64Wjp. Acesso em: 13 jul. 2018.

PEÑA, Miryam. La Declaración Sociolaboral del Mercosur. Su aplicabilidad directa por los Tribunales Paraguayos. Asunción: Instituto de Investigaciones Jurídicas, 2014. Disponível em: https://bit.ly/3my5FfM. Acesso em: 12 nov. 2018.

PIOVESAN, Flávia. Direitos Humanos e o Direito Constitucional Internacional. 16. ed. rev. ampl. e atual. São Paulo: Saraiva, 2016.

RAMÍREZ, Luis Enrique (Coord.). Derecho del Trabajo. Hacia una Carta Sociolaboral Latinoamericana. Buenos Aires/Montevideo: BdeF, 2011.

RODRIGUES DE SOUZA, Alexsander; ALVARES GASPAR, Renata. A incorporação da declaração sociolaboral do Mercosul no ordenamento jurídico brasileiro como norma constitucional de direitos humanos. Revista Iberoamericana de Derecho Internacional y de la Integración, [s. l.], n. 4, p. 222-245, 2016.

SANTOS, Hermelino de Oliveira. Constitucionalização do direito do trabalho no Mercosul. São Paulo: LTr, 1998.

SARDEGNA, Miguel A. Las relaciones laborales en el Mercosul. Buenos Aires: Ediciones La Rocca, 1995.

SILVA, Lenir Aparecida Mainardes da; MANDALOZZO, Silvana Souza Neto. A agenda do trabalho decente no contexto do Mercosul. In: COSTA, L. C.; NOGUEIRA, V. M. R.; SILVA, V. R. (Org.). A política social na América do Sul: perspectivas e desafios no século XXI. Ponta Grossa: Editora UEPG, 2013. p. 113-129. Disponível em: https://bit.ly/3lDnokO. Acesso em: 26 jul. 2018.

SUÑÉ, Natasha. Tribunales Administrativos Internacionales el caso del Tribunal Administrativo Laboral del Mercosur. In: MOLINA DEL POZO, Carlos F. (Dir.). Derecho y Economía de la Integración no 2. Madrid: Juri-Dileyc, 2017.

TAL MERCOSUL. Resolução no 54/03 MERCOSUL/GMC. Montevidéu: Mercosul, 10/xii/03. Disponível em: https://bit.ly/3fr4YnQ. Acesso em: 24 ago. 2020.

TAL MERCOSUL. Sentença definitiva do Tribunal Administrativo Laboral do Mercosul na reclamação interposta por María Del Carmen García contra o Instituto Social do Mercosul. Buenos Aires: Mercosul, 2015. Disponível em: https://bit.ly/36A1s5G. Acesso em: 24 ago. 2020.

TAL MERCOSUL. Sentença definitiva do Tribunal Administrativo Laboral do Mercosul na reclamação interposta por Luis Flores contra o Parlamento do Mercosul - PARLASUL.

Buenos Aires: Mercosul, 2017. Disponível em: https://bit.ly/2KW98Xw. Acesso em: 24 ago. 2020. 
TAL MERCOSUL. Sentenças do Tribunal Administrativo Trabalhista do Mercosul. Assunção: Mercosul, 2020. Disponível em: https://bit.ly/3qpaUka. Acesso em: 24 ago. 2020.

TAL MERCOSUL. Sentencia definitiva del Tribunal Administrativo Laboral del Mercosur en el reclamo interpuesto por Maureen Margaret Mackinnon Gómez contra la secretaria administrativa del Mercosur. Montevidéu: Mercosul, 2005. Disponível em: https://bit.ly/33Bq7VJ. Acesso em: 24 ago. 2020.

TAVARES, André Ramos. Curso de Direito Constitucional. 16. ed. São Paulo: Saraiva, 2018.

TRIBUNAL DE JUSTIÇA DA UNIÃO EUROPEIA. A Instituição. Apresentação. União Europeia, 2020. Disponível em: https://bit.ly/2JNbWpe. Acesso em: 26 ago. 2020.

VIEIRA, Luciane Klein. La Organización Internacional del Trabajo (OIT): sus características, el modus operandi y el derecho producido. In: NEGRO, Sandra Cecilia (Coord.) Organizaciones Internacionales: cuestiones actuales. Bogotá: Ibáñez, 2019. 